\title{
Are Customers Satisfied With Healthier Food Options At South African Fast-Food Outlets?
}

\author{
Michael C. Cant, University of South Africa, South Africa \\ Ricardo Machado, University of South Africa, South Africa \\ Melanie Gopaul, University of South Africa, South Africa
}

\begin{abstract}
Fast-food consumption has been a staple for many people; however, due to rising health concerns, there has been an increasing interest in the consumption of healthier food both in South Africa and elsewhere. Many consumers are demanding better quality foods that offer nutritional benefits. This global trend has led to fast-food outlets adding healthier food options to their menus. Limited literature exists on customer satisfaction with regards to the food quality of these healthier food options. Therefore, the purpose of this article is to determine the level of customer satisfaction with the food quality of healthier food options available at fast-food outlets in South Africa. The study followed a mixed method approach, whereby a self-administered questionnaire was distributed to students at a residential South African University. The results indicate that South African consumers are highly satisfied with the food quality of the healthier food options at fast-food outlets.
\end{abstract}

Keywords: Healthy Fast-Food Options; South African; Customer Satisfaction; Food Quality

\section{INTRODUCTION}

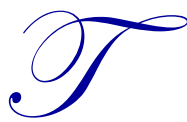

he fast-food industry, worldwide, has been experiencing phenomenal growth (Van Zyl, Steyn \& Marais, 2010:124). This is due to the increased consumption of fast-food (Van Zyl et al., 2010:124), the rise in the number of fast-food outlets (Sipahi, 2010:74) and the global expansion of the fast-food industry (Freemark, 2010:444). Many consumers, however, have also become increasingly concerned about their health and the food that they consume (Euromonitor International, 2011). As a result of this trend, fast-food outlets have been taking steps to introduce healthier food options. The existing literature, however, fails to recognise the level of customer satisfaction with the food quality of the healthier food options available at South African fast-food outlets. There have been international studies that focused on service quality and its link to food choices. Kayra, Kaynak and Kucukemiroglu (1995) compared American and Canadian consumer's perceptions of fast-food restaurants which included variety of menu as a factor. Jain and Gupta (2004) investigated service quality models in India to adapt the models to the fast-food restaurant context in India. These studies did not, however, focus on healthier food options in their respective country studies. This paper therefore aims to determine South African consumers' level of satisfaction with the food quality of the healthier food options available at fast-food outlets. The following section will now briefly provide a background into the South African fast-food industry and obesity levels, followed by the trend towards healthy eating habits, and lastly, customer satisfaction. Thereafter the research methodology employed in this study is discussed followed by the findings, limitations, and the conclusion and recommendations. 


\section{LITERATURE REVIEW}

\section{The Fast-Food Industry}

Fast-food is increasingly consumed by individuals all over the world. The United States population alone is one of the major consumers of fast-food (DeRocco, 2006:122), with approximately 80\% of Americans eating fastfood at least once a month, and about 50\% reporting that they eat it at least once a week (Dugan, 2013;Pilan, 2013). According to Said (2013) the countries that consume the most fast-food, after the United States are France, Canada and the United Kingdom. However, fast-food is not just a phenomenon in the developed countries but also in many developing countries (Misra \& Khurana, 2008:20; Bhuian, 2000:40) including South Africa (Bockle, 2009:8).

South Africans have been described as "...fast-food junkies who are embracing affordable, large-portioned and immediate consumption fast-food" (Franchise Association of South Africa, 2012). According to Maumbe (2010:1), the increase in disposable income and improved living standards has led to more individuals consuming fast-food. Furthermore, De Klerk (2008:17) points out that due to busier lifestyles, fast-food appears to be a convenient option. This is confirmed by Pilon (2013) who reported the top reason for choosing fast-food options in the United States was convenience. Analytix Business Intelligence (2012a) reported that three out of four South Africans, 16 years and older (25.3 million), purchased food from a fast-food outlet in a four-week period in 2011 (figure 1). This figure is expected to reach 34.1 million by 2017 (Planting, 2013).

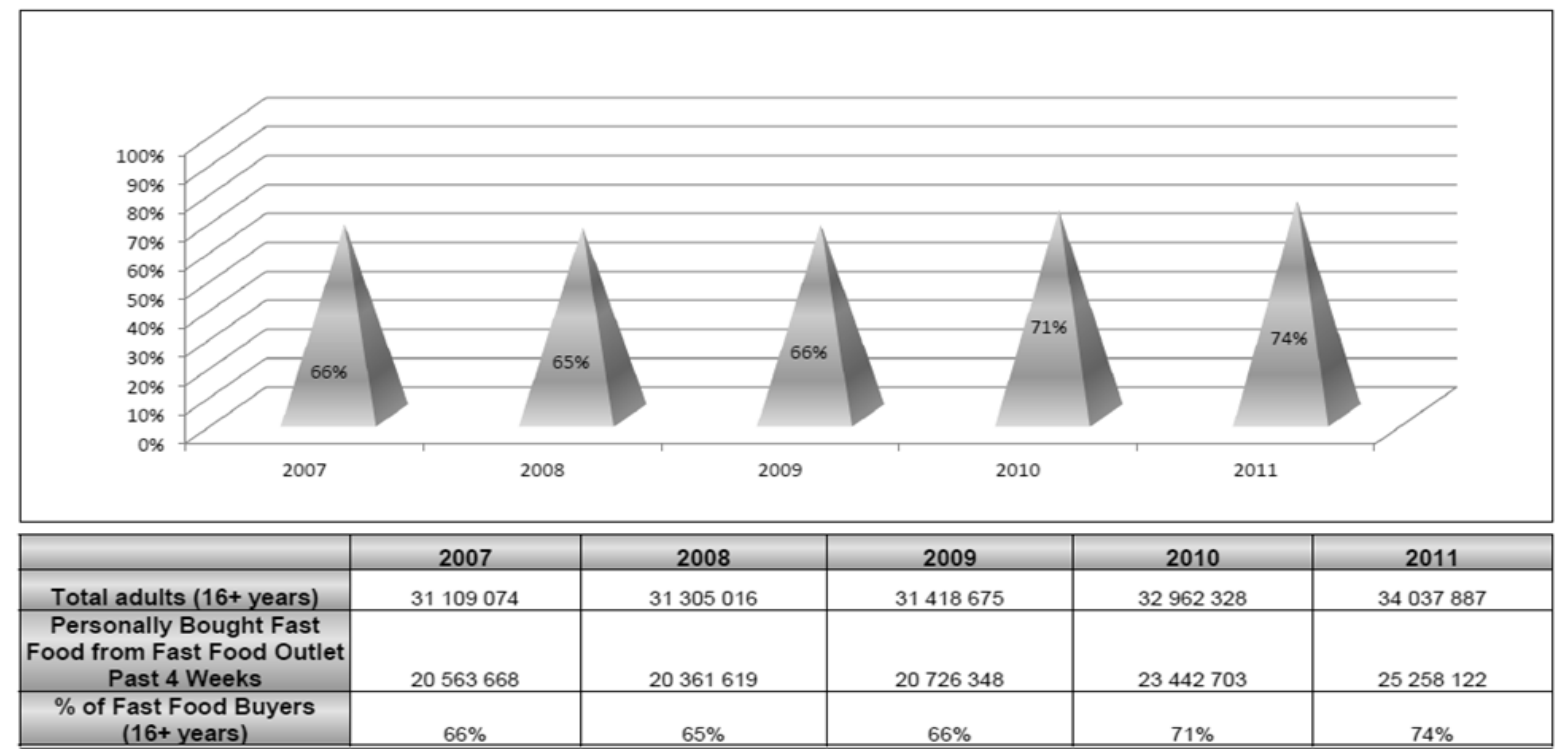

Figure 1: Personal Purchase Of Fast-Food From A Fast-Food Outlet

Source: Analytix Business Intelligence (2012a)

Figure 1 further shows that the percentage of fast-food buyers increased from 66\% in 2007 to $74 \%$ in 2011. Moorad (2012) states that the South African fast-food industry is growing at a rapid pace and there is little indication of a slowdown in the consumption of fast-food in the near future (Naidoo, 2013). Fast-food appears to be South Africa's leading consumer foodservice category, accounting for approximately $40 \%$ of all sales (Produce Marketing Association, 2013). Along with this growth, however, is the considerable attention the industry has been receiving with regard to food being deemed unhealthy (Analytix Business Intelligence, 2012b). Most fast-foods are low in beneficial nutrients and high in fat, calories, salt and sugar (Hales, 2011:149) and have thus received criticism for contributing to obesity (Maumbe, 2010:11; Binkley, 2006:373).

Obesity refers to an excess of body fat (He, Chen \& Feng, 2011:206) and is commonly defined as a body mass index (BMI) of 30.0 or higher (Flegal, Carroll, Ogden \& Curtin, 2010:235). Obesity is considered a worldwide problem (Tomer, 2011:24) and is rising in almost every country (Pediatrics, 2011:201). Globally, about 1.46 billion adults are overweight, 502 million of whom are considered obese (Lilja, 2011:1). Statistics further indicate that 61\% 
of all South Africans are overweight or obese, more specifically; $70 \%$ of women over 35, 59\% of black women 15 years and older, $55 \%$ of white men 15 years and older, $25 \%$ of teens and $17 \%$ of children under 9 years (Mail \& Guardian, 2012). Rosenheck (2008:544) highlights that there is a link between increased fast-food intake and caloric consumption, which makes individuals more susceptible to weight gain and obesity.

Over the years, many individuals have realised the dangers of obesity and its related health risks and have thus become more concerned about their health and wellness (Euromonitor International, 2011).

\section{Move Towards A Healthier Lifestyle}

As much as the fast-food industry has grown throughout the years, so has the move towards a healthier lifestyle. Consumers not only want to consume meals that are quick and convenient, but that also offer nutritional benefits (Euromonitor International, 2011). As a result, many fast-food outlets have added healthier food options to their menus to cater for these consumers (Euromonitor International, 2011). Healthier food options include items such as grilled chicken, fruit and yoghurt, salads, low-fat sandwiches and wraps (El-Baz, 2004:59). However, although fast-food outlets have adapted to the healthy food trend, limited literature exists on customer satisfaction with regards to the food quality of the healthier fast-food options in South Africa, deemed a topic of great significance. Pilon (2013) highlights a study in the United States that shows that $12 \%$ of respondents are very satisfied with the amount of healthier options available at fast-food restaurants, while $51 \%$ of respondents were somewhat satisfied. On the other hand, $36 \%$ of respondents were unsatisfied or very unsatisfied, which is a sizeable percentage of the respondents. As Andaleeb and Conway (2006:3) state, the consumer is the final judge of "...how much to spend and where, when and what to eat".

\section{Customer Satisfaction And Its Importance}

Customer satisfaction can be described as the degree to which customers are happy with the products or services offered by an organisation (Rai, 2008:107). The most commonly accepted theory explaining customer satisfaction according to Ha and Jang (2010:3) is based on the classic theory of Lewin's expectancy-disconfirmation model whereby the cause for satisfaction or dissatisfaction with a product or service is the performance of that product or service relative to the customer's expectations (Mittal, Holbrook, Beatty, Raghubir \& Woodside, 2008:342). When performance meets or exceeds expectations, expectation confirmation takes place and the customer is satisfied. However, when performance fails to meet expectations, expectation disconfirmation occurs and the customer is then dissatisfied (Ha \& Jang, 2010:4).

Customer satisfaction determines an organisation's prolonged existence and financial success (Harrington, Ottenbacher \& Way, 2010:81). Sulek and Hensley (2004:236) highlight the importance of customer satisfaction by emphasising that $90 \%$ of unsatisfied customers never return to the fast-food outlet or restaurant. It is therefore important that fast-food outlets display a strong customer-driven orientation (Harrington et al., 2010:81). With this in mind, fast-food outlets need to measure customer satisfaction on a regular basis in order to determine how successful they are at providing products or services to the satisfaction of their customers (Nimako \&Azumah, 2009:3) and thereby improve marketing strategies. Qin and Prybutok (2008) developed a model to measure service quality in fast-food restaurants in the United States and performed a study exploring the dimensions of service quality, which examined the relationship between service quality, customer satisfaction and behavioural intentions (Qin \& Prybutok, 2009). This study established a link between food quality and satisfaction, and suggested that fastfood restaurant managers could develop better strategies to differentiate their service, such as offering healthier food options to increase their market appeal. Another study by the same authors (Qin, Prybutok \& Zhao, 2010) in China confirmed the positive link between food quality and satisfaction in Chinese fast-food restaurants, and the link was seen as a critical factor in customer's evaluation of satisfaction. These studies have, however, not been replicated in the South African context.

\section{Food Quality}

The aim of this paper was to determine South African consumers' level of satisfaction with the food quality of the healthier food options available at fast-food outlets. Food is the tangible component of the dining experience, 
and as such the part that is more easily evaluated (Kasapila, 2006:24). Food quality can be defined as the features of a product that are essential in determining the degree of acceptability of that product to the consumer (Otegbayo, Samuel, Kehinde, Sangoyomi \& Okonkwo, 2010:541). Food quality was found to be the most important aspect of customer satisfaction in various studies (Sulek \& Hensley, 2004:242; Ng, 2005:48; Kasapila, 2006:112) and has been generally accepted as a significant element of the overall dining experience (Sulek \& Hensley, 2004:236). The current paper was based on the food quality dimension of the Institutional DINESERV Model proposed by $\mathrm{Ng}$ (2005:22) which measures six items of food quality namely: overall quality, taste, eye appeal, freshness, nutritional content and variety.

Taste

Taste refers to the use of taste buds to perceive the four basic tastes, namely sweet, salty, sour and bitter (Sivasankar, 2005:96). According to Sriwongrat (2008:14) taste has been viewed as the most important element of food attributes in a number of fast-food studies. Furthermore, researchers have highlighted the significance of taste by stating that tasty food may increase loyalty and keep customers coming back for more (Kleynhans, 2003:31; Shaharudin, Mansor \& Elias, 2011:206).

Eye Appeal

The eye appeal of food relates to the way food is decorated and how it is visually presented to consumers (Sriwongrat, 2008:15). It is often said that “...one eats with one's eyes first” (Kleynhans, 2003:30). As a result, if the food looks good, consumers are more likely to have the assumption that it tastes good (Kleynhans, 2003:30).

Freshness

Freshness is related to aspects such as aroma, taste and texture (Péneau, Hoehn, Roth, Escher \& Nuessli, 2006:9). Namkung and Jang (2007:394) indicate that previous studies have reported freshness of food as a vital core sign of quality food.

Nutritional Content

Nutritional content refers to what the food is made up of and its impact on the body (Thompson, 2009). Nutritious food has been identified as one of the key aspects in dining satisfaction and return patronage (Namkung\& Jang, 2007:393).

Variety

Food variety refers to the quantity or assortment of different menu items (Namkung \& Jang, 2007:303). Palacio and Theis (2005:155) point out that as customers of foodservice organisations generally comprise of individuals from diverse ethnic, economic and cultural backgrounds, most of whom have different preferences in terms of food, providing a wide variety of food options is thus crucial.

\section{METHODOLOGY}

Data collection was done by means of distributing 400 self-administered questionnaires directly to students at the University of Pretoria in South Africa. The questionnaire contained a total of 8 closed-ended questions, 3 open-ended questions and 2 scaled response questions whereby the degree of customer satisfaction was measured on a five-point Likert scale ranging from "Very dissatisfied(1)" to "Very satisfied(5)". The sampling methodology utilised was that of non-probability, convenience sampling, which enabled the researcher to collect data quickly and easily. The quantitative data was analysed using SAS JMP version 10 and the qualitative data through content analysis using NVivo version 10. The data was edited, coded, cleaned and descriptive statistics (frequency counts) were used to describe the findings. 


\section{FINDINGS}

From the 400 questionnaires received, 4 were removed due to insufficient completion and 60 due to disqualification as discussed next.

\section{Qualifying Questions}

A total of 21 respondents (5.3\%) answered "no" to the first qualifying question: "Do you purchase food from fast-food outlets from time to time?" These respondents were disqualified from participation as the study was interested in retrieving information from those who purchase food from fast-food outlets. The second qualifying question disqualified 39 respondents (10.4\%) who answered "no" to the question: "Are you aware of any healthier food options offered at fast-food outlets?" Respondents had to at least be aware of the healthier food options offered at fast-food outlets in order to continue with the questionnaire. A total of 336 questionnaires were deemed usable for further analysis.

\section{Respondents' Opinion Of What Is Meant By A Healthier Food Option}

The majority of the respondents (156 or $46.4 \%$ ) indicated that healthier food options are items low in fats and oils. A total of 142 respondents $(42.3 \%)$ specified healthier food options as vegetables, followed by salad (116 or $34.5 \%$ ), protein ( 84 or $25 \%$ ), fruit (77 or $22.9 \%$ ), grilled food (67 or 19.9\%), a balanced meal (44 or $13.1 \%$ ), low sugar (38 or $11.3 \%$ ) and a healthy sandwich, wrap or pita (34 or $10.1 \%)$. These results are consistent with the definition provided in this article, which include items such as grilled chicken, fruit and yoghurt, salads, low-fat sandwiches and wraps.

\section{Proportion Of Respondents That Purchased Healthier Food Options}

From the 336 respondents, a total of $238(70.8 \%)$ purchased the healthier food options available at fastfood outlets. Although this percentage represents the majority of the respondents, a significant number (98 or 29.2\%) did not purchase the healthier food options from fast-food outlets. These respondents were asked to provide reasons for their behaviour, whereby majority of the respondents (32 or 32.6\%) indicated that they ate fast food as a treat and therefore did not want to eat healthily when dining out at fast-food outlets. A total of 29 respondents (29.6\%) pointed out that the healthier food options were tasteless and unappealing and 23 respondents $(23.5 \%)$ were of the opinion that it defeated the purpose of eating out at a fast-food outlet. A further 20 (20.4\%) believed that the healthier food options were more expensive or overpriced compared with other options available, followed by 12 $(12.2 \%)$ who were of the opinion that the healthier food options were not that healthy. From these results, it appears that the respondents have negative perceptions towards the taste, presentation, nutrition and price of the healthier food options available which may be aspects that fast-food outlets should look into if they wish to increase their customer base.

The following sections will focus on the 238 respondents who purchased the healthier food options from fast-food outlets.

\section{Frequency Of Purchasing Healthier Food Options}

Most of the respondents (73 or 30.7\%) purchased the healthier food options from fast-food outlets once a month, followed by 54 respondents $(22.7 \%)$ who purchased these options a few times a month, $37(15.5 \%)$ once a week and $35(14.7 \%)$ once every two weeks. Based on these findings, it appears that respondents purchased healthier food options from fast-food outlets quite often, as $94.1 \%$ (224) purchased these options at least once a month. 


\section{Fast-Food Outlets That Respondents Recently Purchased Healthier Food Options From}

The findings indicate that the majority of the respondents (59 or 24.8\%) had most recently purchased healthier food options from Nando's, followed by Kauai (54 or 22.7\%), KFC (38 or 16\%), McDonald's (25 or $10.5 \%)$, Wimpy (18 or $7.6 \%)$ and Steers (10 or $4.2 \%)$.

\section{Demographic Makeup Of Respondents}

A total of $45 \%$ (107) of respondents were male, while 55\% (131) were female. The majority of the respondents (92\% or 219) fell into the 19-23 age category. Since the research was conducted at the University of Pretoria, this may be attributable to the high percentage of respondents within this age category. Racial makeup indicated that the majority of the respondents were White (45.4\% or 108), while the minority of respondents were Asian $(1.7 \%$ or 4$)$.

\section{Customer Satisfaction With Regards To Food Quality}

Overall Quality Of The Food

Figure 2 illustrates the respondents' satisfaction level with the overall quality of the healthier food options.

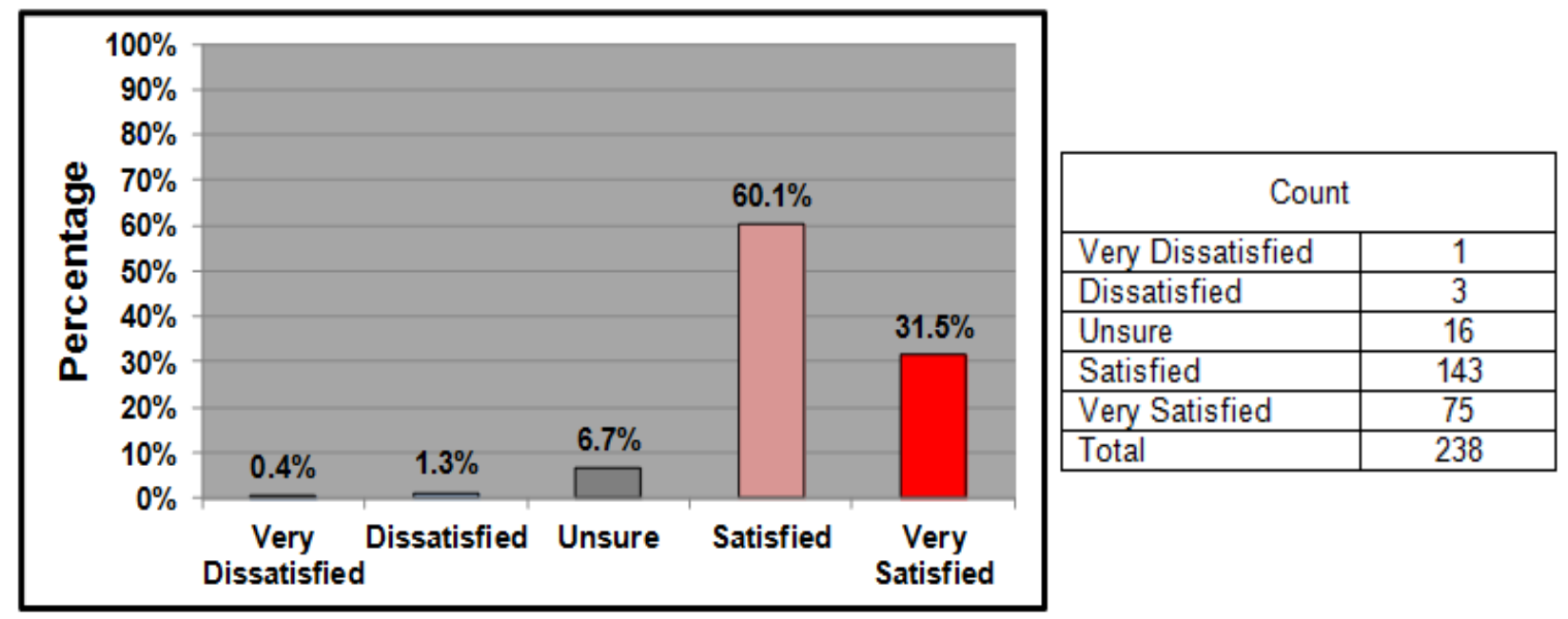

Figure 2: Overall Quality Of The Food $(\mathrm{n}=238)$

Figure 2 indicates that a total of $91.6 \%$ of respondents (218) were satisfied or very satisfied with the overall quality of the healthier food options. Only $1.7 \%$ (4) were dissatisfied or very dissatisfied with it and $6.7 \%$ (16) were unsure. This largely positive response suggests that respondents were satisfied with the overall quality of the healthier food options offered by fast-food outlets.

Taste Of Food

Figure 3 indicates the respondents' satisfaction level with the taste of the healthier food options. 


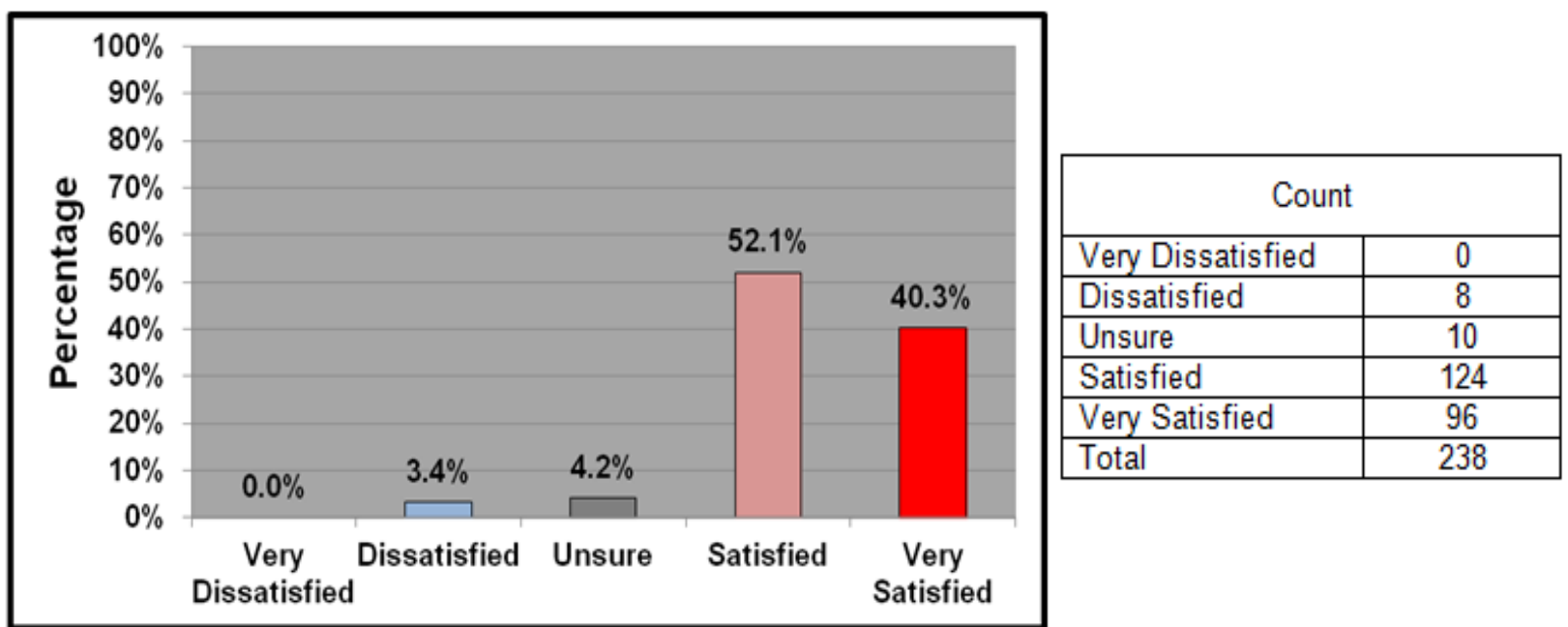

Figure 3: Taste Of Food $(n=238)$

As shown in figure 3,92.4\% of the respondents (220) were satisfied or very satisfied with the taste of the healthier food options available at fast-food outlets. Only 3.4\% (8) were dissatisfied and 4.2\% (10) were unsure. These results indicate that the respondents were pleased with the taste of the healthier food options offered by fastfood outlets.

\section{Eye Appeal Of Food}

Figure 4 indicates the respondents' satisfaction level with the presentation of the healthier food options.

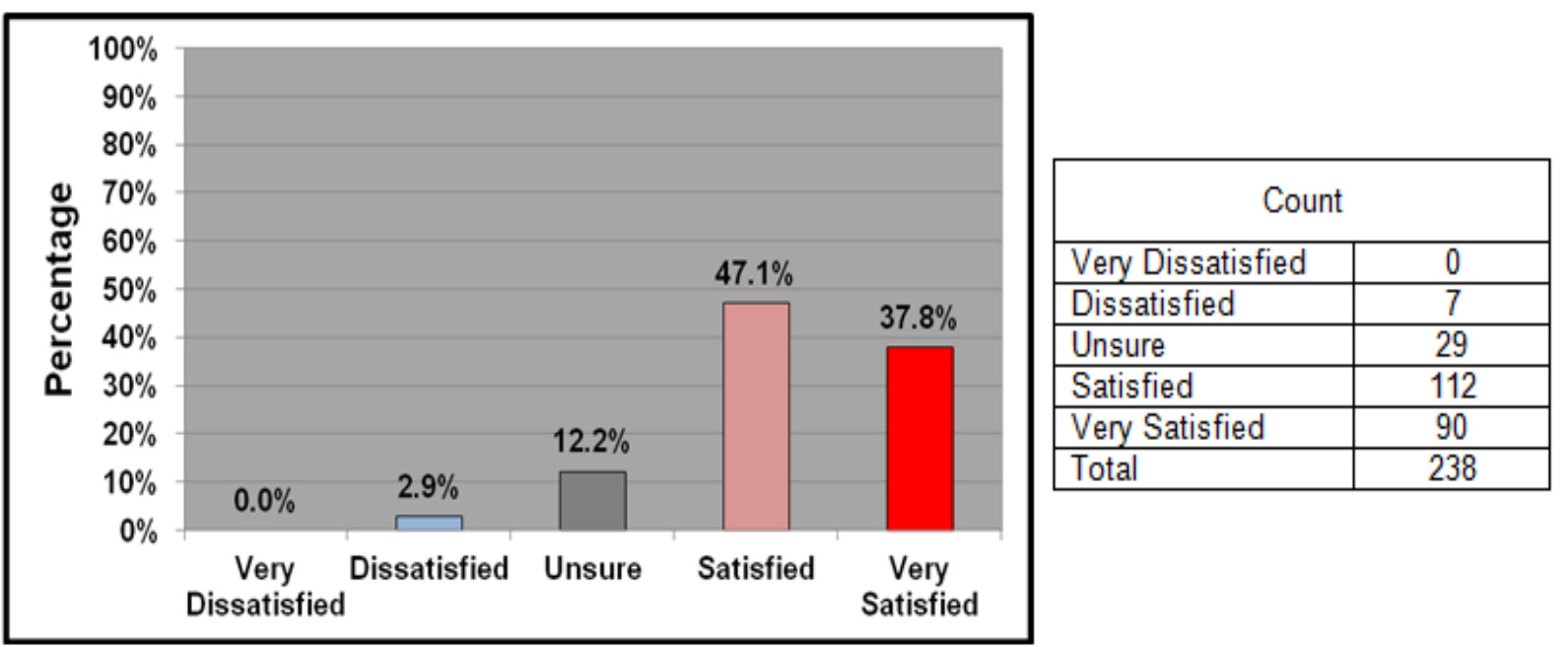

Figure 4: Eye Appeal Of Food $(\mathrm{n}=238)$

From figure 4 , it can be seen that $84.9 \%$ of the respondents (202) were satisfied or very satisfied with the way the healthier food options were presented. Only $2.9 \%$ of respondents (7) were dissatisfied and did not find the healthier food options appealing, while a further 12.2\% (29) were unsure. Although these results reflect positively on fast-food outlets, a significant total of $15.1 \%$ (36) respondents were not happy. Fast-food outlets need to ensure that the healthier food options are presented in a way that is visually appealing. The more appealing the food looks, the more consumers will be willing to consume it (USDA, 2004:4). 


\section{Freshness Of The Food}

Figure 5 describes the respondents' satisfaction level with the freshness of the healthier food options.

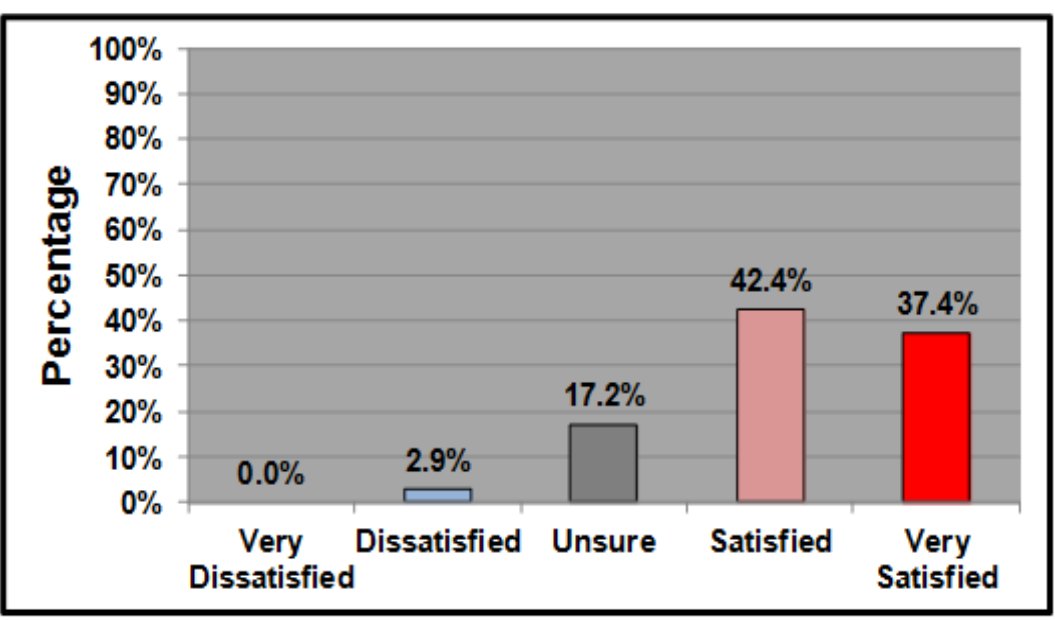

\begin{tabular}{|l|c|}
\hline \multicolumn{2}{|c|}{ Count } \\
\hline Very Dissatisfied & 0 \\
\hline Dissatisfied & 7 \\
\hline Unsure & 41 \\
\hline Satisfied & 101 \\
\hline Very Satisfied & 89 \\
\hline Total & 238 \\
\hline
\end{tabular}

Figure 5: Freshness Of The Food $(n=238)$

Figure 5 shows that $2.9 \%$ of respondents (7) were dissatisfied with the freshness of the healthier food options, while $17.2 \%$ of respondents (41) were unsure. Although the majority of respondents (190 or 79.8\%) were satisfied or very satisfied, indicating that they were happy with the freshness of the healthier food options, it is very concerning that $20.1 \%$ (48) were not satisfied. This could be due to fast-food outlets not using high-quality, fresh ingredients and serving food that is not freshly cooked. Fast-food outlets could maintain food freshness by improving the delivery of raw materials to their outlet through just in time (JIT) deliveries. Delivering raw materials on a regular basis enables the freshness of the food to be preserved at the highest level possible (Shaharudin et al., 2011:206). Furthermore, fast-food outlets should serve food that is freshly cooked. Fresh, well-prepared food creates a positive experience for the consumer, both physically and emotionally (USDA, 2004:6).

\section{Nutritional Content Of The Food} options.

Figure 6 describes the respondents' satisfaction level based on the nutritional content of the healthier food

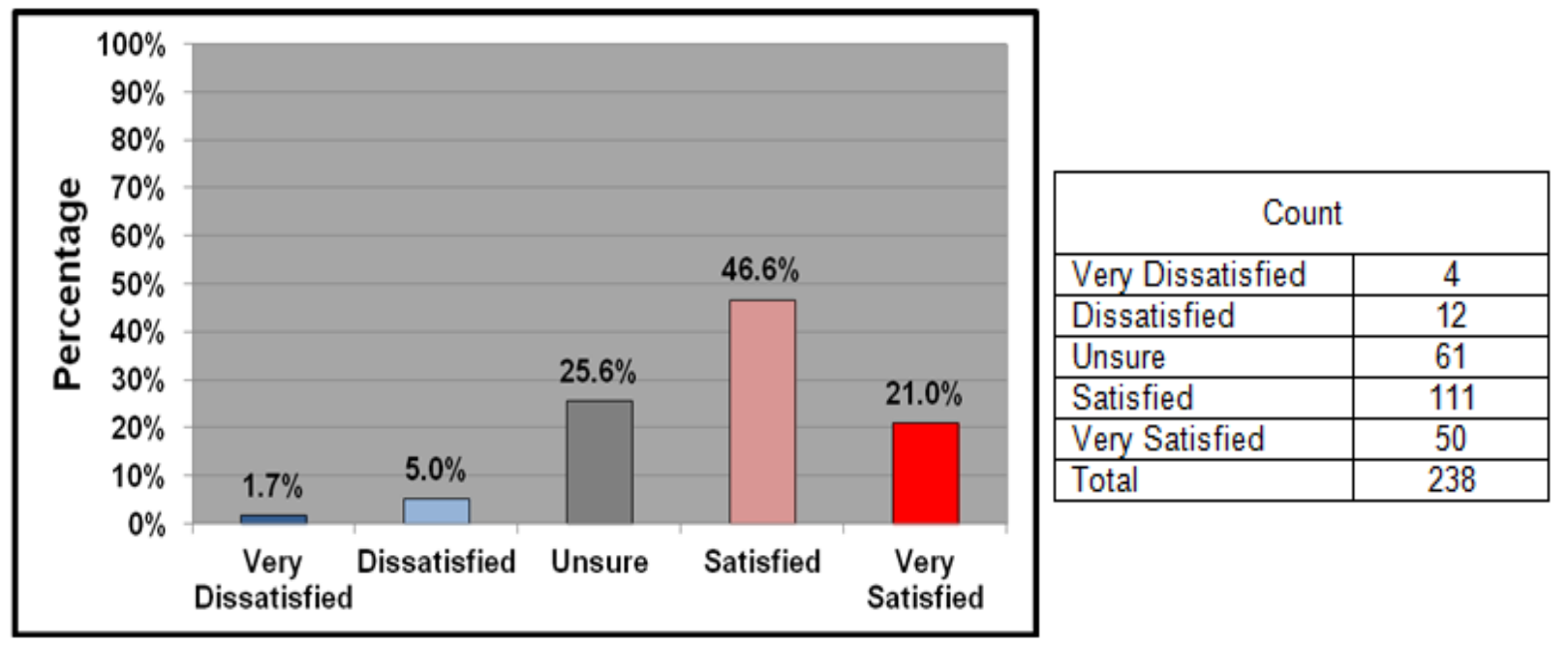

Figure 6: Nutritional Content Of The Food $(n=238)$ 
The findings presented in figure 6 show that only $67.6 \%$ of respondents (161) were satisfied or very satisfied with the nutritional content of the healthier food options. It is interesting to note the large percentage drop in satisfied and very satisfied respondents compared with the other items of food quality previously discussed. Notably, $6.7 \%$ of respondents (16) indicated that the nutritional content of the healthier food options was unsatisfactory, while $25.6 \%$ (61) were unsure. Although the majority of the respondents were positive regarding the nutritional content of the healthier food options, 32.3\% (77) were either unsure or negative. A negative response among respondents may be due to a lack of knowledge regarding the nutritional content of the foods available. Many fast-food outlets do not provide the nutritional information of foods at point of purchase and although some of them do display this information on their websites, it may not be easily accessible to consumers, particularly at the time of purchase. Fast-food outlets need to ensure that their target market is educated and aware of the nutritional content of the healthier food options. Further investigation may also be required in order to establish customer expectations and perceptions regarding the nutritional content of the healthier food options.

\section{Variety Of Mепи Options}

Figure 7 illustrates the respondents' satisfaction level with the variety of healthier food options.

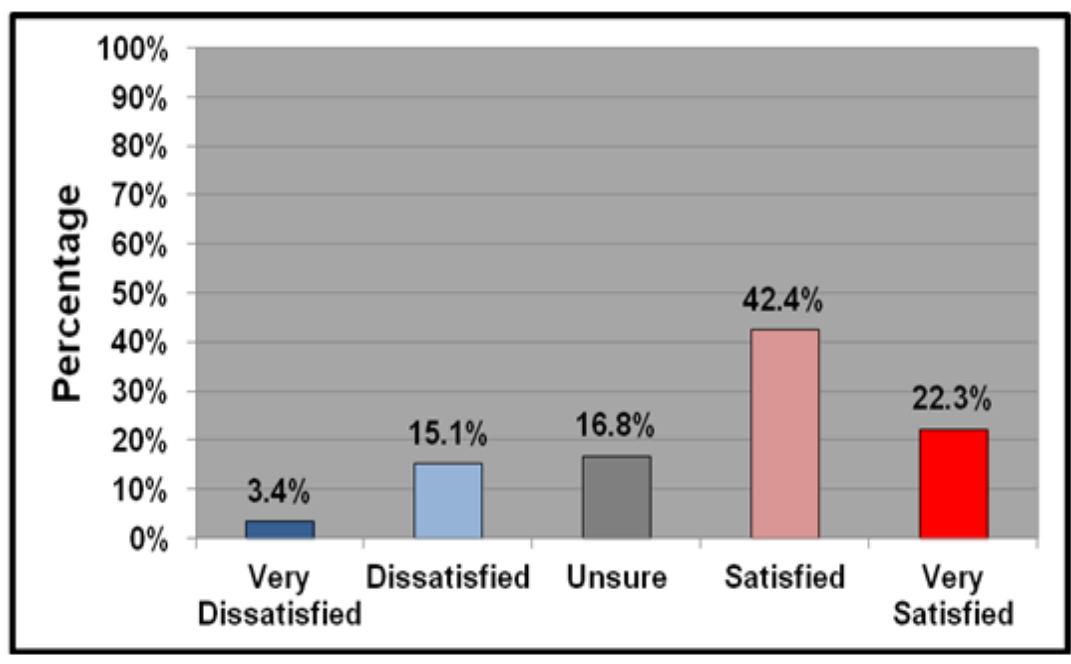

\begin{tabular}{|l|c|}
\hline \multicolumn{2}{|c|}{ Count } \\
\hline Very Dissatisfied & 8 \\
\hline Dissatisfied & 36 \\
\hline Unsure & 40 \\
\hline Satisfied & 101 \\
\hline Very Satisfied & 53 \\
\hline Total & 238 \\
\hline
\end{tabular}

Figure 7: Variety Of Menu Options ( $\mathrm{n=238)}$

As indicated in figure 7, only $64.7 \%$ of the respondents (154) were satisfied or very satisfied with the variety of healthier food options offered by fast-food outlets. Some $18.5 \%$ of respondents (44) were not happy with the variety, while a further $16.8 \%$ (40) were unsure. These results are clearly a cause for concern, as a total of $35.3 \%$ of respondents (84) were either dissatisfied or unsure with the variety of healthier food options offered by fast-food outlets. The variety of menu options seems to have received the lowest satisfaction rating compared with the other items of food quality. These results correlate with the findings of Kasapila (2006:75), where consumers were least satisfied with the variety of menu options. From the findings, it appears that respondents may be limited in their choice of healthier food options at fast-food outlets in South Africa. In this regard, fast-food outlets may find it useful to pay attention to menu variety in their efforts to improve the quality of the healthier food options. The results can be compared to the recent study reported on by Pilon (2013) in the United States which showed that 12\% of respondents were very satisfied with the amount of healthier food options available at fast-food restaurants, $51 \%$ were somewhat satisfied, $23 \%$ were somewhat unsatisfied, and $13 \%$ were very unsatisfied. The ratio of satisfied to unsatisfied is similar in both instances.

\section{Overall Satisfaction With Food Quality}

Figure 8 indicates the respondents' overall satisfaction level with the food quality of the healthy food options. 


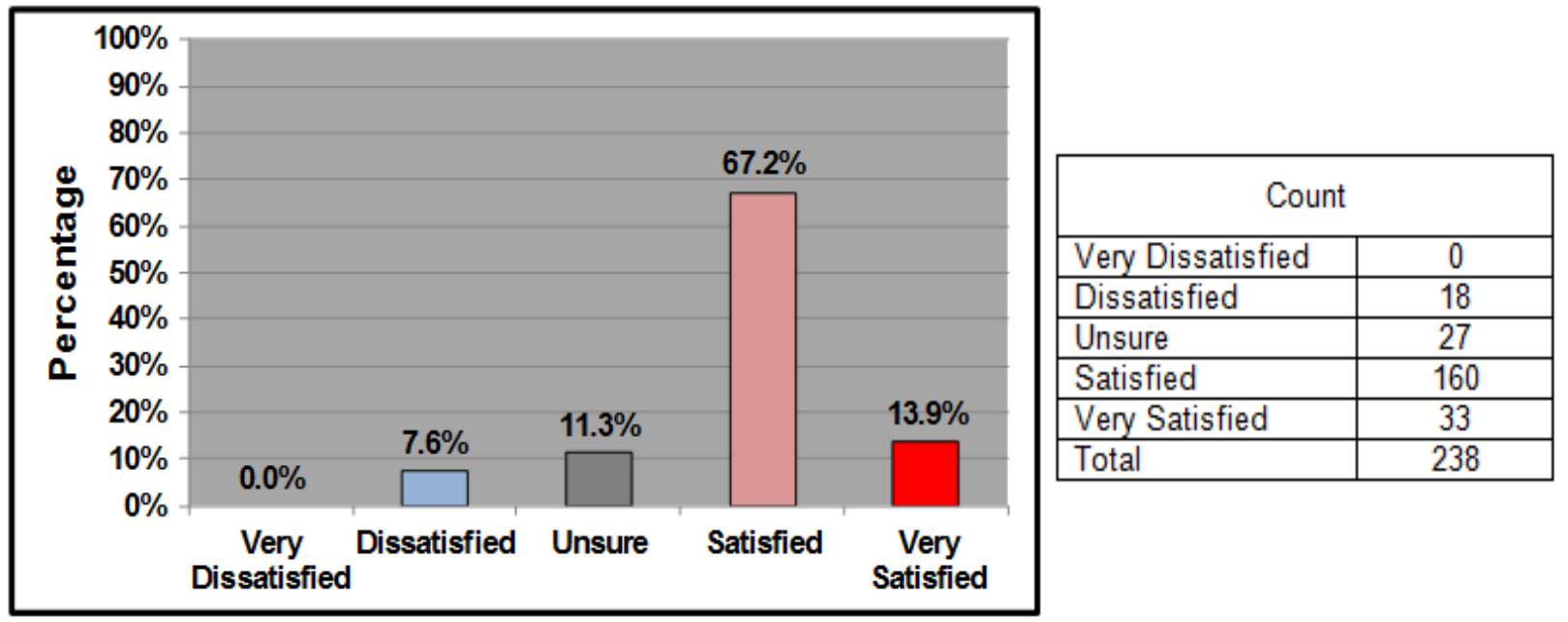

Figure 8: Overall Satisfaction With The Food Quality Of The Healthy Food Options $(n=238)$

Figure 8 shows that $81.1 \%$ (193) of the respondents were satisfied or very satisfied with the quality of the healthier food options at fast-food outlets. Only $7.6 \%$ of the respondents were dissatisfied while $11.3 \%$ were unsure. The findings indicate that respondents were overall satisfied with the quality of the healthier food options available at fast-food outlets.

\section{Suggestions To Improve Food Quality}

Table 1 presents the respondents' suggestions to improve the food quality of the healthier food options available at fast-food outlets.

Table 1: Suggestions To Improve Food Quality $(\mathrm{n}=158)$

\begin{tabular}{|l|c|c|}
\hline Category & Percentage (\%) & Frequency count \\
\hline Wider variety & 34.2 & 26 \\
\hline Fresh food & 16.5 & 20 \\
\hline Cheaper prices & 12.7 & 16 \\
\hline Lower fats and oils & 10.1 & 14 \\
\hline Improve preparation method & 8.9 & 10 \\
\hline Better produce & 6.3 & 6 \\
\hline Indicate nutritional values of food & 5.1 & 6 \\
\hline Advertising & 3.8 & 5 \\
\hline Tastier food & 3.8 & 4 \\
\hline More salads & 3.2 & 4 \\
\hline Better informed staff & 2.5 & 4 \\
\hline Friendlier staff & 2.5 & 3 \\
\hline More presentable food & 2.5 & 3 \\
\hline No preservatives & 1.9 & 2 \\
\hline Better portions & 1.9 & 2 \\
\hline More fruit & 1.3 & 1 \\
\hline Vegetarian options & 1.3 & 1 \\
\hline More outlets & 0.6 & 1 \\
\hline More protein & 0.6 & 1 \\
\hline Self-service & 0.6 & \\
\hline Vegan options & 0.6 & \\
\hline
\end{tabular}

* Total responses may not equal $n$ and percentages may not equal 100 as this question was open-ended. Percentage was calculated using the frequency count per category divided by $n$.

Table 1 shows that the majority of the respondents $(34.2 \%$ or 54$)$ suggested a wider variety. This finding seems to support the results of figure 7 which shows that respondents were mostly dissatisfied with the variety of the 
healthier food options in comparison with all the other items of food quality. Therefore, as mentioned previously, fast-food outlets may find it useful to pay attention to menu variety, specifically adding a wider range of healthier food options in their efforts to improve the quality of food. Table 1 further indicates that $16.5 \%$ (26) of respondents suggested fresh food, followed by cheaper prices (12.7\% or 20$)$ and lower fats and oils $(10.1 \%$ or 16$)$. It is interesting to note that $12.7 \%$ (20) of respondents suggested cheaper prices within the food quality dimension. Price may be a crucial factor for respondents.

\section{LIMITATIONS}

Respondents were selected through the use convenience sampling, which restricted the study in generalising the findings to the larger population. Furthermore, the sample only comprised of students studying at the University of Pretoria in South Africa and it was therefore not geographically representative. Due to fieldwork being conducted during the examination period, the study may have failed to elicit viewpoints of respondents not present on campus at the time. Furthermore, the study was limited to fast-food outlets only.

\section{CONCLUSION AND RECOMMENDATIONS}

The findings seem to indicate a high level of satisfaction among respondents with the food-quality of the healthier food options available at fast-food outlets, with $81.1 \%$ (193) respondents overall satisfied with this dimension. It appears, however, that the respondents were least satisfied with the variety and nutritional content of the healthier food options. It is recommended that fast-food outlets offer a wider range of healthier food options, such as salads, healthy sandwiches, wraps and more grilled options. With regard to the nutritional content, fast-food outlets need to ensure that the healthier food options are lower in fats and oils, and that their target market is educated and well aware of the nutritional content of these options. In this case, fast-food outlets may find it useful to place nutritional information not only on their website, but also at point of purchase, enabling consumers to make appropriate choices. In addition to improving the quality of the healthier food options, it was suggested that fastfood outlets make use of the just in time (JIT) principle for the delivery of their raw materials. Furthermore, fastfood outlets may need to market the healthier food options more aggressively in order to alter negative perceptions towards the taste, presentation, nutrition and price of the healthier food options.

Future research may attempt to employ focus groups to gain deeper insight into respondents' perceptions and views regarding the food quality of the healthier food options available at fast-food outlets. Another opportunity for future research may be to identify a more representative sample to include a diverse group of individuals and not just students. Stewart and Tinsley (1995), in the United States, highlighted this in their study looking at food choices of young adults who are not students. Their results showed a difference in reasons for food choices between clusters of non-student young adults, and this could prove useful research to replicate in South Africa. Another aspect on future research to be considered could be researching the adolescent group of consumers in South Africa, as this would provide insights into the shaping of perceptions with regard to fast-food options before they reach University attendance age. Studies previously done in the United States showed that a broad approach is needed to influence the food choices of adolescents (Neumark-Sztainer, Story, Perry \& Casey, 1999), and this may prove similar in South Africa. Future research could also aim to measure customer satisfaction with specific healthier food options. Alternatively, selecting a specific fast-food outlet may increase the consistency of the findings.

\section{AUTHOR INFORMATION}

Michael C Cant is Professor and head of the Department of Marketing and Retail Management at the University of South Africa (Unisa). He has published over 50 accredited articles in refereed journals and is the editor and author of numerous marketing textbooks. These books are widely prescribed at universities in South Africa. He has presented papers at more than 45 international conferences all over the world and is a well-respected marketing and retail scholar. He holds a D.Com. in Marketing from the University of South Africa. Michael C Cant, D.Com., University of South Africa, Department of Marketing and Retail Management, P.O. Box 329, UNISA, 0003. Email:cantmc@unisa.ac.za 
Mr Ricardo Machado is a senior lecturer in the Department of Marketing and Retail Management at the University of South Arica. He has a wide academic and practical background from management positions in retailing and construction to a senior group marketing manager for a multinational food and beverage company. He has lectured extensively throughout South Africa at undergraduate, post-graduate and executive development programmes. He graduated from the University of Tulsa (USA) with a BSc Cum Laude in Management Science, he then obtained an MBA in Finance and subsequently obtained an Honours degree in Marketing from Unisa. He is a Fellow of the South African Institute of Management. Ricardo Machado, University of South Africa, Department of Marketing and Retail Management, P.O. Box 329, UNISA, 0003. E-mail:machar@unisa.ac.za

Ms Melanie Gopaul is a lecturer in the Department of Marketing and Retail Management at the University of South Arica. She graduated from the University of Pretoria with a BCom (Hons) in Marketing Management and is currently undertaking her Master's degree in Business Management at Unisa. Her areas of interest include customer satisfaction, branding, e-marketing and retail. Melanie Gopaul, University of South Africa, Department of Marketing and Retail Management, P.O. Box 329, UNISA, 0003. E-mail:gopaum@unisa.ac.za

\section{REFERENCES}

1. Analytix Business Intelligence. (2012a). South Africa country report: Fast-food consumer trends (20072011). Retrieved from: http://www.analytixbi.com/images/PDF/SACRFFC001.pdf [Accessed: 02-092012].

2. Analytix Business Intelligence. (2012b). South Africans' love for fast food grows...!'Retrieved from: http://www.bizcommunity.com/Print.aspx?l=178\&c=19\&ct=1\&ci=75913 [Accessed: 05-08-2012].

3. Andaleeb, S.S. \& Conway, C. (2006). Customer satisfaction in the restaurant industry: An examination of the transaction-specific model. Journal of Services Marketing, 20(1): 3-11.

4. Bhuian, S.N. (2000). Saudi consumer preference of fast food outlets. Journal of Food Products Marketing, 6(1):39-52.

5. Binkley, J.K. (2006). The effect of demographic, economic and nutrition factors on the frequency of food away from home. Journal of Consumer Affairs, 40(2):372-391.

6. Bockle, I. (2009). Managerial perceptions of corporate social responsibility and social practices present at McDonald's South Africa. Retrieved from: http://eprints.ru.ac.za/1579/ [Accessed: 14-02-2011].

7. De Klerk, M. (2008).Children's preferences of fast food. Master's thesis. University of Johannesburg.

8. DeRocco, D. (2006). You are what you eat: Stories of food in modern time. Ontario: Full Blast Productions.

9. Dugan, A. (2013). Fast-food still major part of U.S. diet. Retrieved from:http://www.gallup.com/poll/163868/fast-food-major-part-diet.aspx [Accessed: 18-01-2014].

10. El-Baz, M. (2004). Building a healthy lifestyle: A simple nutrition and fitness approach. Lincoln: iUniverse.

11. Euromonitor International. (2011). Fast-food in South Africa. Retrieved from: http://www.euromonitor.com/consumer-foodservice-in-south-africa/report [Accessed: 10-01-2012].

12. Flegal, K.M., Carroll, M.D., Ogden, C.L. \& Curtin, L.R. (2010). Prevalence and trends in obesity among US adults, 1999-2008. American Medical Association, 303(3):235-241.

13. Franchise Association of South Africa. (2012). Survey finds South Africans love fast food. Retrieved from: http://www.fasa.co.za/news/2012/newsletter12/newsletter.html [Accessed: 14-02-2011].

14. Freemark, M. (2010). Pediatric obesity: Etiology, pathogenesis, and treatment. New York: Humana Press.

15. Ha, J. \& Jang, S. (2010). Perceived values, satisfaction, and behavioral intentions: The role of familiarity in Korean restaurants. International Journal of Hospitality Management, 29:2-13.

16. Hales, D. (2011). An invitation to health: Choosing to change. Belmont: Wadsworth Cengage Learning.

17. Harrington, R.J., Ottenbacher, M.C. \& Way, K.A. (2010). QSR choice: Key restaurant attributes and the roles of gender, age and dining frequency. Journal of Quality Assurance in Hospitality \& Tourism, 14(1):81-100.

18. He, Z., Chen, A.B. \& Feng, G.S. (2011). Deciphering the molecular and physiological connections between obesity and breast cancer. Frontiers in Biology, 6(3) 206-212.

19. Jain, S.K. \& Gupta, G. (2004). Measuring service quality: SERVQUAL vs. SERVPERF Scales. VIKALPA 29(2):25-37. 
20. Kayra, A. Kaynak. E. \& Kucukemiroglu, O. (1995). Marketing strategies for fast-food restaurants: a customer view. International Journal of Contemporary Hospitality Management, 7(4): 16-22.

21. Kasapila, W. (2006). Young adults' satisfaction regarding their dining experience in casual dining restaurants in Hatfield, Pretoria. Master's thesis. University of Pretoria.

22. Kleynhans, H.C. (2003). Leisure tourists' satisfaction regarding their meal experience at Lesedi Cultural Village. Master's thesis. University of Pretoria.

23. Lilja, M. (2011). Trends in obesity and type 2 diabetes; ethnic aspects and links to adipokines. Retrieved from: http://umu.diva-portal.org/smash/get/diva2: 455710/FULLTEXT01 [Accessed: 10-03-2012].

24. Mail \& Guardian.(2012). Identifying South Africa's silent killers. Mail \& Guardian, 20 January. Retrieved from: http://mg.co.za/article/2012-01-20-identifying-south-africas-silent-killers [Accessed: 10-05-2012].

25. Maumbe, B.M. (2010). The quick service restaurant industry in South Africa: Market structure, competitive strategies, and research directions. Retrieved from:

https://www.ifama.org/events/conferences/2010/cmsdocs/191_poster_2.pdf [Accessed: 10-01-2011].

26. Misra, A. \&Khurana, L. (2008). Obesity and the metabolic syndrome in developing countries. Journal of Clinical Endocrinology \& Metabolism, 93(11):9-30.

27. Mittal, B., Holbrook, M., Beatty, S., Raghubir, P. \& Woodside, A. (2008). Consumer behavior. Cincinnati: Open Mentis.

28. Moorad, Z. (2012). Fast food market in SA growing rapidly. Retrieved from: http://www.bdlive.co.za/business/retail/2012/11/20/fast-food-market-in-sa-growing-rapidly [Accessed: 1212-2012].

29. Naidoo, N.C. (2013). South Africa consumed by culture of eating out. Retrieved from: http://www.cnbcafrica.com/news/southern-africa/2013/10/24/safrica-consumed-by-an-eating-out-culture/ [Accessed: 17-11-2013].

30. Namkung, Y. \& Jang, S. (2007). Does food quality really matter in restaurants? Its impact on customer satisfaction and behavioural intentions. Journal of Hospitality and Tourism Research, 31(2) 387-410.

31. Neumark-Sztainer, D., Story, M., Perry, C. \& Casey, M.N. (1999). Factors influencing food choices of adolescents: findings from focus-group discussions with adolescents. Journal of the American Diabetic Association, 99(8) 929-938.

32. Ng, Y.N. (2005). A study of customer satisfaction, return intention, and word-of-mouth endorsement in university dining facilities. Master's thesis.Oklahoma State University.

33. Nimako, S.G. \&Azumah, F.K. (2009). An assessment and analysis of customer satisfaction with service delivery of mobile telecommunication networks within Ghana. Master's thesis. Luleå University of Technology.

34. Otegbayo, B.O., Samuel, F.O., Kehinde, A.L., Sangoyomi, T.E. \& Okonkwo, C.C. (2010). Perception of food quality in yams among some Nigerian farmers. African Journal of Food Science, 4(8) 41-549.

35. Palacio, J.P. \& Theis, M. (2005). Introduction to foodservice. 10th ed. Upper Saddle River: Prentice Hall.

36. Pediatrics.(2011). Policy statement-Children, adolescents, obesity and the media. Retrieved from: http://pediatrics.aappublications.org/content/128/1/201.full.pdf [Accessed: 13-06-2011].

37. Péneau, S., Hoehn, E., Roth, H.R., Escher, F. \& Nuessli, J. (2006). Importance and consumer perception of freshness of apples. Food Quality and Preference, 17(1/2) 9-19.

38. Pilon, A. (2013). Fast food survey: customers mostly satisfied with healthy options. Retrieved from: http://aytm.com/blog/daily-survey-results/fast-food-survey/ [Accessed: 29-03-2014].

39. Planting, S. (2013). South Africans' healthy appetite for fast food. Retrieved from: http://www.moneyweb.co.za/moneyweb-south-africa/south-africans-healthy-appetite-for-fast-food [Accessed: 17-11-2013].

40. Produce Marketing Association. (2013). Foodservice environment. Retrieved from: http://www.pma.com/global/south-africa [Accessed: 17-11-2013].

41. Qin, H. \& Prybutok, V.R. (2008). Determinants of customer-perceived service quality in fast-food restaurants and their relationship to customer satisfaction and behavioural intentions. The Quality Management Journal, 15(2): 35-50.

42. Qin, H. \& Prybutok, V.R.(2009). Service quality, customer satisfaction, and behavioural intentions in fastfood restaurants. International Journal of Quality and Service Sciences, 1(1): 78-95.

43. Qin, H. Prybutok, V.R. \& Zhao, Q. (2010). Perceived service quality in fast-food restaurants: empirical evidence from China. International Journal of Quality and Reliability Management, 27(4): 424-437. 
44. Rai, A.K. (2008). Customer relationship management: Concepts and cases. New Delhi: PHI Learning.

45. Rosenheck, R. (2008). Fast food consumption and increased caloric intake: A systematic review of a trajectory towards weight gain and obesity risk. Obesity Reviews, 9: 535-547.

46. Said, S. Countries that consume the most fast food or junk food. Retrieved from:http://www.therichest.com/expensive-lifestyle/location/countries-that-consume-the-most-fast-food-orjunk-food/ [Accessed: 10-02-2014].

47. Shaharudin, M.R., Mansor, S.W. \& Elias, S.J. (2011). Food quality attributes among Malaysia's fast food customer. International Business and Management, 2(1): 198-208.

48. Sipahi, S. (2010). Expanding operations in fast-food industry under uncertain market conditions. International Journal of Trade, Economics and Finance, 1(1): 74-79.

49. Sivasankar, B. (2005). Food processing and preservation. New Delhi: PHI Learning.

50. Sriwongrat, C. (2008). Consumers' choice factors of an upscale ethnic restaurant. Master's thesis. Lincoln University.

51. Stewart, B. \& Tinsley, A. (1995). Importance of food choice influences for working young adults. Journal of the American Diabetic Association, 95(2): 227-231.

52. Sulek, J.J. \& Hensley, R.L. (2004). The relative importance of food, atmosphere, and fairness of wait: The case of a full-service restaurant. Cornell Hospitality Quarterly, 45(3): 235-247.

53. Sunday Times.(2013). Sunday Times Top Brands 2013. Sunday Times, August 1:30.

54. Thompson, N. (2009). What is the meaning of nutritional value? Retrieved from: http://www.livestrong.com/article/63090-meaning-nutritional-value/ [Accessed: 17-11-2013].

55. Tomer, J. (2011). What causes obesity? And why has it grown so much? Challenge, 54(4):22-49.

56. USDA. (2004). Meal appeal: Attracting customers. Retrieved from: http://teamnutrition.usda.gov/Resources/meal_appeal.pdf [Accessed: 10-05-2013].

57. Van Zyl, M.K., Steyn, N.P. \& Marais, M.L. (2010).Characteristics and factors influencing fast food intake of young adult consumers in Johannesburg, South Africa. South African Journal of Clinical Nutrition, 23(3): 124-130. 